\title{
Działalność wydawnictw pedagogicznych w Kielcach w latach 1955-2012 na przykładzie Wydawnictwa Pedagogicznego ZNP w Kielcach i Wydawnictwa MAC
}

Kielce należą do ważniejszych ośrodków wydawniczych w Polsce, także jeśli chodzi o publikowanie książek, czasopism pedagogicznych, metodycznych pomocy dydaktycznych. Przedmiotem niniejszego opracowania uczyniono dwa wydawnictwa edukacyjne: Wydawnictwo Pedagogiczne Związku Nauczycielstwa Polskiego (ZNP) w Kielcach oraz Wydawnictwo MAC.

Szerzej na temat działalności wydawnictwa ZNP w okresie 1955-1995 pisali Jerzy Jarowiecki ${ }^{1}$ oraz Mieczysław Adamczyk², ja natomiast ograniczę się jedynie do zasygnalizowania ważniejszych faktów z dziejów tej instytucji. Początki Wydawnictwa Pedagogicznego ZNP sięgają 1955 r., kiedy to w Sandomierzu funkcjonował Powiatowy Ośrodek Doskonalenia Kadr Oświatowych. Ówczesny instruktor języka polskiego Mieczysław Wolski podjął inicjatywę wydawania „Biuletynu Powiatowego Ośrodka Doskonalenia Kadr Oświatowych w Sandomierzu. Język Polski”3. Zespołem redakcyjnym kierowała Karolina Pojawska. Czasopismo ukazywało się w postaci maszynopisu, bez zgody cenzury, którą uzyskano dopiero w 1959 r. Pismo pod tym tytułem wychodziło do roku 1966, wtedy zmieniono tytuł na „Biuletyn Zarządu Okręgu Związku Nauczycielstwa Polskiego Wydział

* Dr, Uniwersytet Jana Kochanowskiego w Kielcach, Wydział Humanistyczny, Instytut Bibliotekoznawstwa i Dziennikarstwa, Zakład Dziennikarstwa, 25-406 Kielce, ul. Świętokrzyska 21D.

1 J. Jarowiecki, Czterdziestolecie działalności edytorskiej Wydawnictwa Związku Nauczycielstwa Polskiego w Kielcach (1955-1995), „Zeszyty Wszechnicy Świętokrzyskiej” 1997, z. 6, s. 7-32.

2 M. Adamczyk, Biuletyn Zarządu Okręgu Związku Nauczycielstwa Polskiego w Kielcach - "Język Polski”. Próba charakterystyk, „Studia Kieleckie” 1981, z. 2/30.

3 J. Jarowiecki, Czterdziestolecie działalności ... s. 7. 
Pedagogiczny w Kielcach". Jednak siedzibę redakcji do Kielc przeniesiono dopiero w 1970 r. W latach 1967-1980 powstały odrębne serie czasopism:

1. „Materiały Metodyczne dla Nauczycieli Języka Polskiego w Klasach VVIII" (1971-1980);

2. "Język Polski. Materiały metodyczne dla nauczycieli klas I-IV”(1971-1976);

3. „Język Polski. Biuletyn dla szkół średnich” (1967-1971).

Czasopisma dzięki praktycznemu ukierunkowaniu zyskiwały zasięg ogólnopolski, co uwidoczniało się nie tylko w geografii prenumeratorów, ale i autorów tekstów.

Wraz z kolejnymi reformami oświaty zmieniały się tytuły czasopism. Ostatecznie jednak $w$ latach osiemdziesiątych ukształtował się następujący asortyment publikacji ( $w$ tej postaci przetrwał do reformy szkolnictwa z 1999 r.):

1. Czasopisma:

- „Nauczanie Początkowe” wydawane od 1977;

- „Język Polski w klasach IV-VIII”, wychodzący od 1980 do 1998/1999;

- „Język Polski w Szkole Średniej”.

2. Książki z zakresu pedagogiki oraz metodyk nauczania różnych przedmiotów.

Po reformie szkolnictwa z 1997 r. wydawano następujące tytuły czasopism:

1. „Nauczanie Początkowe” - dwumiesięcznik, od rocznika 2003/2004 ukazuje się jako kwartalnik;

2. „Język Polski w Gimnazjum” do 1999/2000 - kwartalnik;

3. "Język Polski w Szkole Średniej” ukazywał się w latach 1986/19872000/2001, od rocznika 2001/2002 wydawany jako "Język Polski w Liceum” - kwartalnik.

Dla nauczycieli klas I-III szkoły podstawowej przeznaczono dwumiesięcznik „Nauczanie Początkowe”. Pismo ukazuje się od 1977 r. w formacie B5. Funkcję redaktora naczelnego pełniła od 1984 r. Irena Chruściel. Periodyk uznawany jest za wartościową pomoc metodyczną przez nauczycieli pochodzących z całej Polski, o czym świadczą nakłady. Przykładowo w roku szkolnym 1991/1992 nakład wyniósł 50000 egzemplarzy. Odbiorcami dwumiesięcznika są najczęściej początkujący nauczyciele poszukujący konspektów lekcji, cyklów lekcyjnych i przykładów ćwiczeń związanych z wybranymi zagadnieniami programowymi lub metodycznymi z poszczególnych przedmiotów. Nacisk kładziono także na opis pomocy naukowych, które uatrakcyjniłyby lekcje i wpłynęły na większą kreatywność ucznia. Rocznie drukowano sześć numerów, a temu ostatniemu nadawano charakter monograficzny, na przykład w roku szkolnym 1993/1994 była to Praca dydaktyczno-wychowawcza z lekturą szkolną.

Po jedenastu latach pracy nad redagowaniem dwumiesięcznika Irenę Chruściel na tym stanowisku zastąpił Tomasz Jóźwicki, ale kierował zespołem redakcyjnym tylko przez rok. Kolejnym redaktorem naczelnym, tj. od rocznika 1997/1998, został Gustaw Treliński. Natomiast od rocznika 2002/2003 obowiązki te przejął Zdzisław Ratajek i pełni je do dzisiaj. Wtedy też ukształtował się układ treści, który z niewielkimi zmianami przetrwał do końca roku 2012. Wyodrębnić można następujące działy: I. Teoretyczne podstawy edukacji 
wczesnoszkolnej; II. Doświadczenia i projekty; III. Scena szkolna; IV. Dziecko sześcioletnie w szkole; V. Nauczyciel XXI wieku - inspiracje metodyczne; VI. Bibliografie i recenzje.

Poprzednikiem „Języka Polskiego w Gimnazjum”, którego pierwszy rocznik ukazał się w roku szkolnym 1999/2000, był „Język Polski w Szkole. Materiały metodyczne dla klas IV-VIII". Pismo to ukazywało się od 1980 r. jako dwumiesięcznik. Redaktorem naczelnym była Elżbieta Doroszkiewicz. Czasopismo miało wtedy czterodziałowy układ treści: część pierwszą tworzyły rozprawy i artykuły autorstwa pracowników naukowych, drugą - propozycje metodyczne, część trzecią stanowiły materiały pomocnicze, tj. rozkłady materiału, testy, sprawdziany itp., część ostatnią przeznaczono na wymianę doświadczeń nauczycieli z pracy z uczniami. Nakład rozchodził się w większości w prenumeracie. W latach osiemdziesiątych przeprowadzono badania sondażowe oraz analizę zamówień prenumeraty. W ich wyniku okazało się, że czasopismo cieszyło się popularnością zwłaszcza wśród nauczycieli z małych miasteczek i wsi, tam gdzie utrudniony był dostęp do bibliotek, poradników metodycznych itp. Czasopismo przydatne było zarówno początkującym nauczycielom, jak i tym odznaczającym się długim stażem pracy, gdyż także oni zobligowani byli aktualizować swą wiedzę i konfrontować osobiste doświadczenia z innymi nauczycielami.

W latach dziewięćdziesiątych redakcja pisma w podtytule informowała, że jest to „dwumiesięcznik wydawany przy współudziale Towarzystwa Literackiego im. Adama Mickiewicza. Oddział w Kielcach”. Od roku 1995/1996 redakcją periodyku kierowała Barbara Myrdzik. Jak już wcześniej wspomniano, od roku 1999/2000 pismo ukazywało się pod tytułem „Język Polski dla klas IV-VI”. Czytelnikom zaproponowano inny układ treści - sześciodziałowy, tj.: Przemiany edukacji; W stronę praktyki; Ewaluacja osiągnięć szkolnych uczniów; W stronę teorii; Rozmowy - kontrowersje - opinie; Prezentacje, przeglądy, recenzje. Nazwy działów numerów wyraźnie sugerowały chęć pomocy nauczycielom wobec wyzwań, które niosła nowa reforma oświaty. Już od rocznika 2000/2001 dokonano zmiany nazwy kwartalnika na „Język Polski w Szkole - Gimnazjum”.

W roczniku 2001/2002 redakcję trzech numerów powierzono Jerzemu Rurawskiemu. Dokonano też niewielkiej korekty nazwy periodyku na „Język Polski w Gimnazjum". W omawianym roczniku uporządkowano układ działów, wprowadzając: I. W stronę teorii; II. W stronę nowego warsztatu; III. W stronę ewaluacji; IV. Recenzje, przeglądy, opinie; V. Polemicznie i przekornie.

Kolejną zmianę redaktora naczelnego należy odnotować już od czwartego numeru rocznika 2001/2002. Wtedy zespołem kwartalnika kierowała Alicja Krawczyk. Po pięciu latach nastąpiła kolejna zmiana i od roku 2006/2007 na odwrocie strony tytułowej periodyku podawano jako redaktora naczelnego Wydawnictwa - Teresę Bugajską.

Kwartalnik „Język Polski w Szkole Średniej” wydawany był od roku szkolnego 1986/1987. Funkcję redaktora naczelnego pisma metodycznego pełniła Jadwiga Adamczak. Zawartość treściową pisma stanowiły rozprawy, eseje i materiały metodyczne autorstwa naukowców z różnych ośrodków Polski (m.in. z Wrocławia - Mieczysław Inglot, z Krakowa - Anna Marzec, Stanisław Bortnowski), ale także 
artykuły polonistów praktyków. Strukturę czasopisma tworzyły - przez kilka roczników - następujące działy: I. Wiedza o literaturze; II. Wiedza o sztuce i filozofii; III. Nauka o języku; IV. Wiedza z zakresu ćwiczeń w mówieniu i pisaniu; V. Aktualności; VI. Rozkłady materiału, propozycje. Prezentowanie literatury w kontekście filozofii, etyki, sztuki oraz kultury sprzyjało nadawaniu edukacji polonistycznej twórczego charakteru, uświadamiało integrację z innymi naukami i interdyscyplinarność. Od roku 1996/1997 funkcję redaktora naczelnego pisma powierzono Alicji Krawczyk. Po trzech rocznikach (tj. od 1999/2000) jako redaktor naczelny figuruje Barbara Myrdzik. Kolejną osobą na tym stanowisku od nru 3 rocznika 2000/2001 był profesor Jerzy Rurawski. Od numeru czwartego rocznika 2001/2002 zmieniono tytuł kwartalnika na „Język Polski w Liceum”, jednocześnie powołując nowego (po raz drugi) redaktora - Alicję Krawczyk. Materiał treściowy podzielono na następujące działy: W stronę teorii; W stronę ewaluacji; W stronę nowego warsztatu; Opinie.

Od roku 2006/2007 w stopce redakcyjnej kwartalnika - podobnie jak w pozostałych tytułach wydawanych przez Wydawnictwo ZNP w Kielcach - podawano jako redaktora naczelnego wydawnictwa Teresę Bugajską, natomiast redaktorem prowadzącym uczyniono Ewę Nowel. Wtedy też ukształtował się następujący układ działowy kwartalnika: I. Od fascynacji do metody - bliżej metody, II. Projekt - lektura szkolna, III. Na poczet kolejnej reformy szkolnej, IV. Tematy, kierunki, inspiracje, opinie. Od rocznika 2009/2010 kwartalnik ukazuje się z podtytułem „Zeszyty kieleckie”. Spośród zmian personalnych należy wspomnieć, że w stopce redakcyjnej drugiego numeru z rocznika 2010/2011 wymieniono jako redaktora Joannę Piastę-Siechowicz. Natomiast - od kolejnego numeru aż do chwili obecnej - obowiązki redaktora naczelnego pełni Ewa Nowel.

Szczegółowe omówienie zawartości poszczególnych zeszytów znajdą zainteresowani w artykule Marii Cyran ${ }^{4}$. Autorka wymienionego tekstu upatrywała przeznaczenia periodyku w "dążeniu do tego, aby pozostawać [kwartalnik] - mimo wszelkich oświatowych zawirowań - ważnym miejscem wymiany poglądów, ośrodkiem świadomego przekraczania granic zawodowych przyzwyczajeń i ogniskiem nowoczesnego myślenia nauczycieli"

Czasopisma, ze względu na swą praktyczność, tj. skoncentrowanie na konspektach lekcji, rozkładach materiału, dostały się pod ostrzał krytyki, ale udało im się przetrwać i na stałe zdobyć prenumeratorów w całej Polsce. Argumentem broniącym redaktorów pisma i autorów była sugestia, że materiały te są w sposób kreatywny wykorzystywane przez nauczycieli i dostosowywane do możliwości uczniów.

Kolejnym z omawianych wydawnictw jest Wydawnictwo MAC Edukacja, które powstało w sierpniu 1989 r. Nazwa MAC pochodzi od inicjałów imion założycieli rodzinnej firmy, tj. Mariusza, Adama i Czesława Cyrańskich. Nieoficjalna siedziba wydawnictwa mieściła się w prywatnym domu rodziny Cyrańskich przy

${ }^{4}$ M. Cyran, Od „Języka Polskiego w Szkole Średniej” do „Języka Polskiego w Liceum” czyli moje spotkania z kieleckim kwartalnikiem polonistycznym, „Język Polski w Liceum” 2007/2008, nr 4, s. $91-104$.

5 Tamże, s. 91. 
ulicy Granitowej w Kielcach. Początkowo sami właściciele rozwozili podręczniki do księgarń oraz szkół ${ }^{6}$. Na magazyn książek wykorzystywano natomiast garaże sąsiadów. Oficjalną siedzibą firmy był budynek przy ulicy Mielczarskiego. Obowiązki kierownika redakcji pełnił Jarosław Machnicki, którego w 2001 r. zastąpił Krzysztof Chrobot.

Pierwszą książką wydaną przez tę oficynę była Muzyka w szkole. Klasa 1 i 2. Materiały metodyczne, wraz z załączoną kasetą magnetofonową.

Z firmy rodzinnej w dość szybkim tempie rozwinął się biznes przynoszący zyski. W dużym stopniu przyczyniło się do tego przywiązywanie dużej wagi do kontaktów z gronem pedagogicznym. Dzięki konsultacjom, promocjom książek oraz systematycznym badaniom rynku stale poszerzało się grono wiernych odbiorców i czytelników.

W trosce o poziom doskonalenia nauczycieli - pod auspicjami MAC-a - w 2000 r. powołano Niepubliczne Centrum Kształcenia Nauczycieli (NCKN). Dyrektorem NCKN została dr Krystyna Kafel: "Głównym celem NCKN jest wspieranie placówek oświatowych, a więc zarówno całych rad pedagogicznych, jak i indywidualnych nauczycieli w osiąganiu coraz wyższego rozwoju poprzez systematyczne wzbogacanie wiedzy oraz doskonalenie umiejętności pedagogicznych i organizacyjnych"7. W 2002 r. przemianowano nazwę placówki na Centrum Doskonalenia Nauczycieli Edukator. Reforma oświaty z 1999 r. wymusiła na nauczycielach konieczność zmiany specjalizacji lub poszerzenie posiadanych kwalifikacji. Centrum zapewniało nauczycielom kompleksowe szkolenia z profesjonalnymi trenerami. Szkolenia te były płatne, ale odpłatność obejmowała jedynie koszty materiałów, co spowodowało ich dużą popularność wśród kadry nauczającej. Tematyka zajęć była podporządkowana aktualnym potrzebom edukacyjnym. Centrum Doskonalenia Nauczycieli prowadziło badania, wywiady, a także rozdawano uczestnikom kursów arkusze ewaluacji. Dzięki analizom tych dokumentów oferta trafiała w potrzeby nauczycieli. Rozwijała się również baza szkoleń w postaci tworzenia regionalnych oddziałów CDN. Powstał nawet osobny cykl konferencji pod nazwą $W$ drodze ku lepszej szkole, podczas których Wydawnictwo MAC Edukacja promowało podręczniki, materiały pomocnicze oraz pomoce dydaktyczne.

Centrum Doskonalenia Nauczycieli działało także na rzecz uczniów, organizując dla nich konkursy służące poszerzaniu i popularyzowaniu wiedzy oraz jej systematyzowaniu. Były to m.in. Tydzień z Sienkiewiczem, Spotkania z Twórczością Edwarda Stachury itp.

Centrum Doskonalenia Nauczycieli Edukator zawiesiło swą działalność z końcem 2007 r. Większość jego zadań przejęło Centrum Doradczo-Szkoleniowe PROFED.

Kadrę na początku działania wydawnictwa stanowili głównie młodzi dziennikarze, którzy wraz z rozwojem firmy kształcili swoje umiejętności. Z czasem

${ }^{6}$ K. Rudnik, Grupa Edukacyjna S.A. - wydawca podręczników MAC Edukacja. Marketing i promocja [mpis pracy magisterskiej napisanej pod kier. M. Siudy], Kielce 2009.

7 Zbiory archiwalne Krystyny Kafel. 
poszerzono współpracę z pedagogami, psychologami, doradcami metodycznymi, pracownikami wyższych uczelni.

Warto dodać, że w czerwcu 2005 r. otwarto Księgarnię MAC Edukacja w Kielcach przy ulicy Paderewskiego. Na piętrze tej placówki zorganizowano kącik dla dzieci, aby bawiły się zabawkami edukacyjnymi, podczas gdy ich rodzice mogli skoncentrować się na wyborze książek w znajdującej się na parterze księgarni.

W Wydawnictwie MAC Edukacja od początku przywiązywano dużą wagę do promocji oferty wydawniczej. Konsultanci działu promocji badają potrzeby nauczycieli poprzez wywiady, bezpośrednie spotkania, ankiety (połączone z wręczaniem upominków osobom odsyłającym wypełniony kwestionariusz w terminie). Organizowane bywają spotkania z autorami serii podręcznikowych. Do promowania wykorzystuje się także Internet, a dokładniej serwis - e-podręcznik. Serwis podzielono na pięć kategorii:

- Wychowanie przedszkolne;

- Kształcenie zintegrowane;

- Klasy IV-VI;

- Gimnazjum;

- Liceum.

Na zawartość serwisu składają się scenariusze zajęć, gry i zabawy dydaktyczne, recenzje, opinie o podręcznikach, linki do przydatnych i ciekawych stron internetowych.

Wydawnictwo rozrastało się - najpierw w grudniu 2005 r. przejęto warszawskie wydawnictwo JUKA-91, specjalizujące się w książkach dla przedszkolaków, uczniów szkół podstawowych, gimnazjów i liceów. Następnie w 2007 r. pod skrzydła MAC-a dostało się wydawnictwo Poltext, publikujące książki z zakresu: ekonomii, zarządzania, finansów, bankowości, ubezpieczeń, marketingu. W wyniku tych działań i przekształceń organizacyjnych powołano 21 września 2007 r. Grupę Edukacyjną S.A., wkraczając jednocześnie na Giełdę Papierów Wartościowych. Nie zapomniano także o działalności charytatywnej, m.in. dofinansowano opiekę medyczną dla kieleckich pięcioraczków.

Sukcesu Wydawnictwa MAC należy upatrywać w różnorodności oferty, także w nowoczesnej promocji i marketingu. Wśród asortymentu firmy należy wymienić:

1. Książki edukacyjne:

- podręczniki dla uczniów,

- przewodniki metodyczne dla nauczycieli,

- inne publikacje dla wszystkich poziomów nauczania, tj. pomoce dydaktyczne (wycinanki, tablice demonstracyjne, testy, tabliczki z książeczkami z serii „Logico Primo” - dla przedszkolaków oraz "Logico Picolo” - dla starszych dzieci.

2. Czasopisma z cyklu „Forum Nauczycieli”:

- „Forum Nauczycieli Przedszkola”,

- „Forum Nauczycieli. Nauczanie Zintegrowane”,

- „Forum Nauczycieli. Szkoła Podstawowa IV-VI. Edukacja humanistyczna”,

${ }^{8}$ http://www. Mac.pl [dostęp: 27.11.2012]. 
- „Forum Nauczycieli. Szkoła Podstawowa IV-VI. Edukacja matematyczno-przyrodnicza",

- „Forum Nauczycieli Gimnazjum”,

- „Forum Nauczycieli Liceum”.

Na szczególne podkreślenie zasługuje działalność Wydawnictwa MAC w zakresie publikowania książek edukacyjnych. Od 1990 do 2011 r. wydano ponad 700 tytułów publikacji zwartych, dla porównania Wydawnictwo ZNP w Kielcach w latach 1980-2011 opublikowało około 80 tytułów.

Czytelnikom Wydawnictwo MAC oferuje kompletne zestawy książek i pomocy dydaktycznych, materiałów pomocniczych dla ucznia i dla nauczyciela. Publikacje tworzone są już dla dzieci od trzeciego roku życia. Taki pakiet, noszący tytuł Trzylatek. Bawię się i uczę, obejmuje dla przedszkolaka książkę i karty pracy. Natomiast w skład kompletu przeznaczonego dla nauczyciela weszły:

- program wychowania przedszkolnego Moje Przedszkole,

- przewodnik metodyczny,

- plan pracy wychowawczo-dydaktycznej,

- Przykładowe wpisy do dziennika zajęć. Trzylatek. Bawię się i uczę.

Na podobnej zasadzie powstały koncepcje pakietów dla cztero-, pięcio- i sześciolatków. Dla tej kategorii wiekowej zaproponowano też książkę omawiającą nową metodę czytania, tzw. odimienną, którą oparto na założeniach pedagogiki konstruktywistycznej ${ }^{9}$. To metoda alternatywna w stosunku do powszechnie w Polsce stosowanej metody analityczno-syntetycznej.

Następną wartą wyeksponowania serią, którą wydawnictwo MAC wprowadziło na rynek polski oraz adaptowało do naszych realiów - jest gra dydaktyczna Logico ${ }^{10}$. Zestaw Logico obejmuje plastikową tabliczkę z przesuwanymi guzikami oraz książki ze specjalnie opracowanymi kartkami służącymi do nauki czytania, pisania i liczenia. Kolorowe przesuwne guziki w fazie wstępnej znajdują się na dole tabliczki. Każdej odpowiedzi odpowiada jedno kolorowe kółeczko. Dziecko wybiera kółeczko i przesuwa w miejsce przez niego wybrane, czyli wyżej do otworów zlokalizowanych wzdłuż brzegów z prawej strony tabliczki. Właściwą odpowiedź może potwierdzić, zaglądając na odwrotną stronę karty (tabliczki).

Dla kształcenia zintegrowanego klas I-III powstały pakiety obejmujące:

- dla ucznia: dziesięcioczęściowy podręcznik, zeszyt do ćwiczeń domowych dla dzieci o zachęcającym tytule Domowniczek, wycinanki oraz zeszyt do ćwiczeń Lekturnik,

- dla nauczyciela: program zintegrowanej edukacji w klasach I-III Moja szkoła oraz przewodniki metodyczne zawierające m.in. sprawdziany, zestaw ćwiczeń dodatkowych oraz propozycje scenariuszy zajęć zintegrowanych Dzień bez podręcznika.

Wydawnictwo proponuje podręczniki, zeszyty ćwiczeń, przewodniki metodyczne, testy i sprawdziany, tablice i plansze demonstracyjne, dzienniki z języka polskiego, matematyki, języka angielskiego. Nauczyciele mogą także skorzystać

9 I. Majchrzak, Nazywanie świata - odimienna metoda nauki czytania, Kielce 2007.

10 G. Bednarski, Wstęp, [w:] Katalog wydawniczy MAC 2007 [okładka, s. 2], Kielce 2007. 
z poradnika Logopedia11 oraz pomocniczych zeszytów ułatwiających ćwiczenia ortograficzne, kaligraficzne i inne.

Również na poziomie gimnazjum Wydawnictwo MAC oferuje publikacje $z$ języka polskiego, informatyki, plastyki, muzyki, chemii, fizyki, biologii oraz książki pomocnicze $z$ edukacji regionalnej. Do wielu z materiałów przeznaczonych dla nauczycieli dołączane są płyty CD.

Nauczycielom i uczniom liceów proponuje się książki i publikacje pomocnicze z języka polskiego, biologii, chemii, fizyki i astronomii, a także edukacji filozoficznej, podstaw przedsiębiorczości, technologii informacyjnej itp.

Tak szeroki wachlarz oferty edukacyjnej obrazuje duży potencjał Wydawnictwa MAC Edukacja oraz możliwości reagowania na potrzeby nauczycieli.

Tabela 1. Liczba tytułów pozycji książkowych publikowanych przez Wydawnictwo MAC Edukacja

\begin{tabular}{|c|c|c|c|c|c|}
\hline Rok & Liczba tytułów & Rok & Liczba tytułów & Rok & Liczba tytułów \\
\hline 1986 & - & 1995 & 2 & 2004 & 49 \\
\hline 1987 & - & 1996 & - & 2005 & 38 \\
\hline 1988 & - & 1997 & - & 2006 & 21 \\
\hline 1989 & - & 1998 & - & 2007 & 1 \\
\hline 1990 & 1 & 1999 & 1 & 2008 & 5 \\
\hline 1991 & - & 2000 & 5 & 2009 & 116 \\
\hline 1992 & - & 2001 & 77 & 2010 & 77 \\
\hline 1993 & 11 & 2002 & 153 & 2011 & 71 \\
\hline 1994 & 4 & 2003 & 79 & & \\
\hline
\end{tabular}

Uwaga: Od 2010 r. uwzględniono książki wydawane przez MAC Edukacja Grupa Edukacyjna.

Źródło: obliczenia własne autorki na podstawie bazy „Przewodnik Bibliograficzny” Biblioteki Narodowej.

Od 2002 r. Wydawnictwo MAC drukowało także cykl czasopism pod wspólnym tytułem „Forum Nauczycieli”. W ciąg roku ukazywały się nieregularnie dwa numery. Od 2005 r. w Internecie były dostępne „Forum Nauczycieli Gimnazjum” oraz „Forum Nauczycieli Liceum”. Niestety, obecnie nie ma do nich dostępu na stronie internetowej wydawnictwa ani nie zachowano ich w archiwum. Była to ciekawa inicjatywa, szkoda że z niej zrezygnowano.

Do rozwoju wydawnictw pedagogicznych - w sposób pośredni - przyczyniło się rozporządzenie Ministra Oświaty i Wychowania z 16 sierpnia 1991 r. dotyczące wykazu podręczników i książek pomocniczych do przedmiotów ogólnokształcących na rok szkolny 1991/1992 ${ }^{12}$. W ten sposób obok monopolisty w zakresie

11 E. Chmielewska, Logopedia. Zabawy logopedyczne i nie tylko, Kielce 2007.

12 Dziennik Urzędowy Ministra Oświaty i Wychowania 1991, nr 4, poz. 26. 
publikacji edukacyjnych, jakim były Wydawnictwa Szkolne i Pedagogiczne, mogły rozwinąć się także inne oficyny. Mimo że opisywane w tym artykule wydawnictwa przeszły różną drogę rozwojową, należy podkreślić duże zasługi Wydawnictwa MAC w zakresie wprowadzania do polskich szkół nowych metod nauczania na przykład czytania, nowych gier dydaktycznych - seria Logico, które w sposób atrakcyjny wprowadzają uczniów w świat wiedzy i nauki. Obie oficyny wydają pisma dla nauczycieli, jednak Wydawnictwo ZNP, mające wieloletnie tradycje w tym zakresie, przetrwało różne okresy zmian społecznych, oświatowych oraz politycznych i - miejmy nadzieję - nadal będzie oferowało znane i uznane tytuły czasopism: „Nauczanie Początkowe”, „Język Polski w Gimnazjum”, „Język Polski w Liceum". 